\title{
Translation, cultural adaptation to Brazil and validation of the venous leg ulcer quality of life questionnaire (VLU-QoL-Br)
}

\author{
Renata Boldrin de Araújo ${ }^{1}$, Maria Rita Parise Fortes², luciana Patrícia Fernandes Abbade ${ }^{3}$, Hélıo Amante Miot* \\ ${ }^{1}$ Medical student at the FMB-Unesp, Botucatu, SP, Brazil \\ ${ }^{2}$ Biologist at the Dermatology Department of the FMB-Unesp, Botucatu, SP, Brazil \\ ${ }^{3}$ Assistance professor and doctor at the Dermatology Department of the FMB-Unesp, Botucatu, SP, Brazil \\ ${ }^{4}$ Assistance professor and doctor at the Dermatology Department of the FMB-Unesp, Botucatu, SP, Brazil
}

Study conducted by the Dermatology and Radiotherapy Department of the FMB-Unesp, Botucatu, SP, Brazil

Article received: $2 / 6 / 13$ Accepted for publication: $1 / 13 / 14$ ${ }^{\star}$ Correspondence:

Departamento de Dermatologia e Radioterapia da FMB-Unesp S/N Address: Campus Universitário de Rubião Jr. Botucatu, SP - Brazi ZIP Code: $18.618-000$ Phone / Fax: +55 14 3882-4922 heliomiot@fmb.unesp.br

http://dx.doi.org/10.1590/1806-9282.60.03.014 Conflict of interest: none

\section{SUMMARY}

Objective: translating the Venous leg ulcer quality of life questionnaire (VLU-QoL), and culturally adapting it to Brazilian Portuguese and validate it with patients at the Hospital das Clínicas of the Botucatu Medical School - Unesp.

Methods: the questionnaire was translated by a professional translator and two dermatologists specialized in the area of venous ulcers (VU), reformulated in a meeting of the three translators. The construct ( $V L U-Q o L-B r)$ was submitted to pre-interviews with ten $\mathrm{VU}$ patients for adaptation of the language. Subsequently, it was applied to patients at the HC-Unesp, and for test-retest reliability for verification of its reproducibility.

Results: 82 patients were evaluated, with $56(68 \%)$ women. The age average was 67.3 years. The questionnaire was translated, adapted and applied to the patients. The construct presented high internal consistency (alpha $=0.94)$ and adequate item-total correlation. When the 32 retests were evaluated, an intra-class correlation was noted for concordance of 0.78 ( $\mathrm{p}<0.01)$, indicating good reproducibility of the construct. The confirmatory factor analysis corroborated the dimensions of the original questionnaire: activities, psychologies, and symptoms. VLU-QoL-Br scores were associated, independently, to the total area of the ulcers and a lower education level of the subjects $(\mathrm{p}<0.01)$.

Conclusion: the translation, adaptation and validation of the VLU-QoL-Br questionnaire were concluded, demonstrating good psychometric performance, and enabling its clinical use in Brazil. It is important to evaluate its performance in other regions and different samples of individuals.

Uniterms: leg ulcer, venous insufficiency, varicose ulcer, quality of life, validation studies.

\section{INTRODUCTION}

Chronic leg ulcers are defined as lesions situated below the knee with a duration of more than six weeks. ${ }^{1}$ They represent an important aggravation to public health as they affect $3.6 \%$ of adults in western countries. ${ }^{2,3}$ They present different etiologies (arterial, venous or mixed), however, around $70 \%$ of cases are classified as venous ulcers (VU) resulting from chronic venous insufficiency. ${ }^{1}$

Owing to their recurrent nature and the long time between opening and healing, VUs present a large eco- nomic and social impact with a negative influence of patient quality of life (QoL). ${ }^{4}$ The treatment cost, clinical complications, labor limitations and work days lost, reduction in the pleasure of daily activities, interference in self-esteem, damage to family and social relationships are factors that interfere in carrying for such patients. ${ }^{5}$

Generic QoL questionnaires do not adequately represent the aspects specifically related to VU. Therefore, specific instruments are needed to contribute to estab- 
lishing clinical care based on the real needs of the individual. $^{6}$

Up to now, the only specific QoL instrument for VU translated and adapted to the Portuguese language is the Charing Cross Venous Ulcer Questionnaire, which has not yet been validated for use in Brazil. ${ }^{7-10}$

The British questionnaire Venous Leg Ulcer Quality of Life questionnaire (VLU-QoL) was validated in its country of origin and covers issue relating to the patient's activities, their psychological conditions and the symptoms of the ulcers. ${ }^{11}$

The objective of this study was to translate the VLUQoL to Brazilian Portuguese, adapt it to the Brazilian reality and validate it with patients at the Hospital das Clínicas (HC) of the Botucatu Medical School (FMB) - Unesp, so that it can be used in the evaluation of QoL for Brazilian patients with VU.

\section{Methods}

The project was carried out at the chronic ulcer outpatient clinic at the FMB-Unesp, involving adult patients of both sexes with venous leg ulcers during consultations in the period from March 2012 to April 2013. There was no interference in the indication or course of treatment of the patients for the conducting the interviews.

The diagnosis of VU was based on the clinical assessment and evidence of signs of chronic venous insufficiency. Patients with no tibial pulse and/or ankle-brachial index below 0.9 were excluded.

A casual sample was taken, consecutively including all eligible and available patients. The sample size was based on previous quality of life study protocols using minimum samples of 80 individuals for the validation process of the construct. ${ }^{12}$

Based on the guidelines for cultural adaptation of psychometric scales, ${ }^{13}$ and with the consent of the original authors of the questionnaire (Asha Hareendran and Tara Symonds) the translation of the VLU-QoL questionnaire was undertaken by a professional translator, who did not know the objective of the study, as well as two specialists in the area of dermatology and VU proficient in English. Subsequently, a consensual synthesis of the translations was undertaken in a meeting of the three translators.
The translated construct was submitted to a pre-interview with ten $\mathrm{VU}$ patients to evaluate their comprehension of the questionnaire and the adaptation of the language. The translation was compared to the original construct.

The questionnaire was developed for self-completion, applied to patients from the same institution and reapplied up to 60 days later during outpatient clinic returns by the same interviewer on 32 patients (test-retest) for verification of the reliability of the construct.

After applying the questionnaire, the patients' demographic and clinical information was evaluated. The variation in the total VLU-QoL-Br scores according to sex, age, education level, evolution time of the active ulcers, number of ulcers and ulcer area as evaluated using the generalized linear model. The total scores of the latent dimensions of the questionnaire were compared using the repeated measures ANOVA technique.

The internal consistency of the questionnaire developed and the latent dimensions was tested using Cronbach's alpha coefficient, excluding retesting. It was considered consistent if it reached a minimum coefficient of 0.8 . The item total correlation was also tested and the effect of subtracting the items in the consistency of the questionnaire, with important items that considered as those modifying the coefficient by less than 0.1 units. ${ }^{14}$

The reproducibility of the construct was tested by comparing the interviews (test-retest reliability). The total score was evaluated in relation to the concordance using the intra-class correlation coefficient (ICC-absolute agreement) and presented in a Bland-Altman diagram. ${ }^{15,16}$

The items from the VLU-QoL-Br were compared with the latent dimensional structure of the original construct using confirmatory factor analysis. ${ }^{14}$

Patient data was analyzed using SPSS 20 and AMOS software. A value of $\mathrm{p}<0.05$ was considered as significant. ${ }^{17}$ The study was approved by the institution's research ethics committee ( $\left.\mathrm{n}^{\circ} 057 / 2012\right)$.

\section{Results}

$56(68 \%)$ of the 82 patients interviewed were women. The average age ( \pm standard deviation) was $67.3( \pm 13.9)$ years, varying from 32 to 86 years. The main clinical and demographic variables are shown in Table 1. 
TABLE 1 Main clinical and demographic data of the patients interviewed

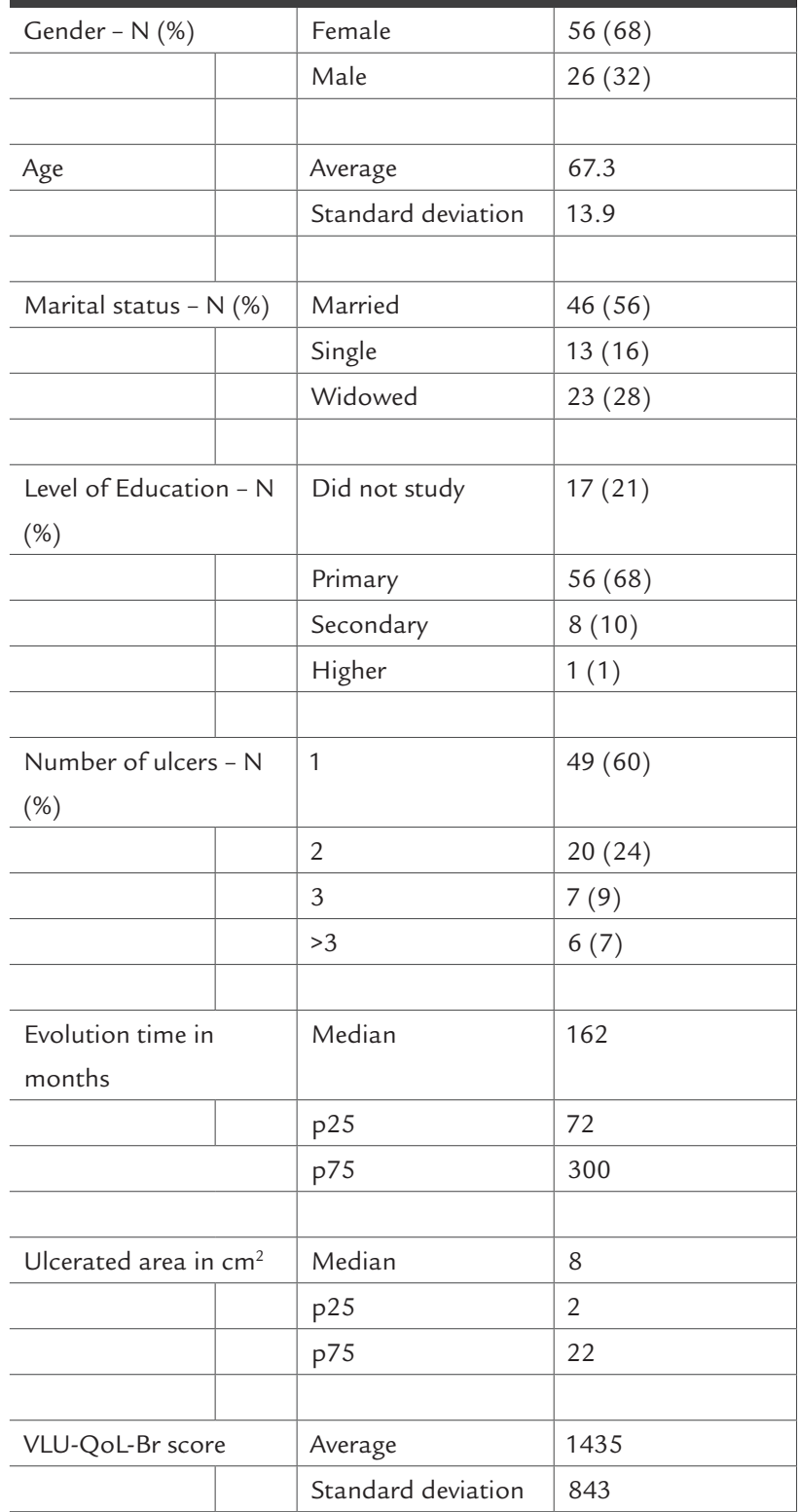

The questionnaire was translated, adapting the language and application to the patients (Chart 1). The translation maintained the characteristics of the original construct. There was no significant difference $(\mathrm{p}=0.63)$ in the impact between the dimensions: symptoms (mean score \pm standard deviation $=491 \pm 288)$, psychological $(470 \pm 349)$ and activities ( $473 \pm 364)$.

All of the patients agreed to the interviews and the questionnaires took 8 to 30 minutes for conclusion. The main element identified as causing delays was patient distraction.
The construct displayed high internal consistency (Cronbach's $\alpha=0.94$ ), and its dimensions presented coefficients: 0.91 (activities); 0.91 (psychological) and 0.88 (symptoms). When excluding variables, the variation of the coefficient was less than 0.01 , and the correlation between each item and the construct was higher than 0.33 .

When retesting was evaluated, a high intra-class correlation was found for interviews conducted within 30 days $(\mathrm{n}=19$; ICC $=0.90)$ and 60 days $(\mathrm{n}=32$; ICC $=0.78)$, indicating adequate reproducibility of the construct (Figure 1). The average time between retesting was 38 days.

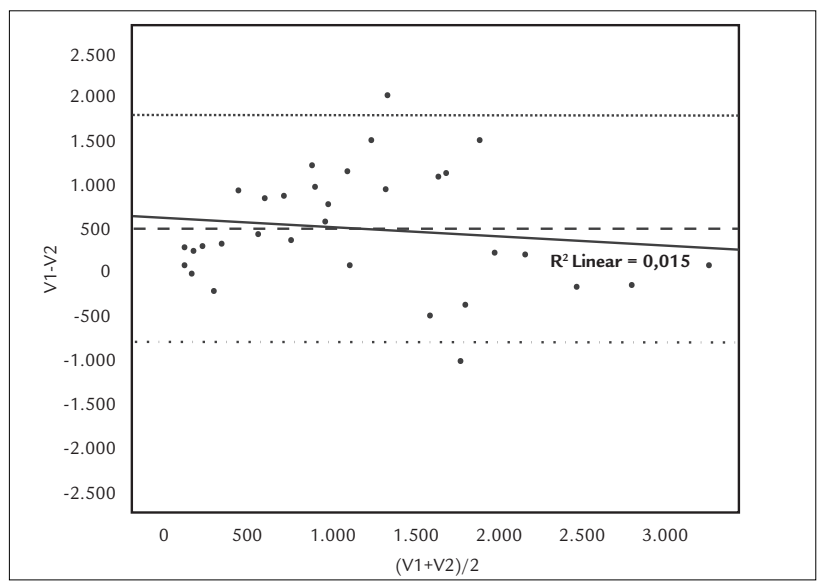

FIGURE 1 Bland-Altman diagram for evaluation of test-retest concordance in less than 60 days $(n=32)$. The mean score $( \pm$ standard deviation) of visit 1 (V1) was $1417( \pm 851)$ and visit 2 (V2), de $954( \pm 928)$.

The confirmatory factor analysis corroborated the latent structure of the original questionnaire, with all of the items presenting significant standardized coefficients $(p<0.01)$ greater than 0.43 for each dimension of the construct. The three dimensions selected explained up to $52 \%$ of the questionnaire's variance.

The VLU-QoL-Br scores were associated to tot total area of the ulcers (coefficient $\beta=4.9 ; \mathrm{p}<0.01$ ) and lower educational level $(\beta=682.00 ; p<0.01)$, independent of age $(\beta=-11.50 ; p=0.18)$, gender $(\beta=-203.60 ; p=0.39)$, active ulcer time $(\beta=0.22 ; \mathrm{p}=0.82)$ and number of ulcers $(\beta=65.17$; $\mathrm{p}=0.55)$.

\section{Discussion}

The VLU-QoL questionnaire was translated, cultural adapted and validated for Brazilian Portuguese. The translation presented adequate internal consistency (total and latent dimensions), reproducibility and corroborated the 
CHART 1 Brazilian version of the questionnaire (VLU-QoL-Br)

In relation to your ulcer(s), IN THE LAST WEEK:

RESPOND: 0. No/never, 25. Rarely, 50. Sometimes, 75. Often, 100. Always/every time

\begin{tabular}{|c|c|c|}
\hline Dimensions & Questions & POINTS \\
\hline \multirow[t]{12}{*}{ Activities } & Did your ulcers impede the completion of activities outside the home? & \\
\hline & Did your ulcers impede the completion of daily activities (e.g. work)? & \\
\hline & Did you ulcers prevent you from leaving your home? & \\
\hline & Did your ulcers impede activities within the home? & \\
\hline & Did your ulcers impede movement or locomotion on foot? & \\
\hline & Do you depend on others because of the ulcers? & \\
\hline & Did your ulcers prevent you from doing the things you like? & \\
\hline & Did your ulcers make the completion of common activities slower? & \\
\hline & Did your ulcers compromise or negatively affect your social life? & \\
\hline & Did your ulcers prevent you from doing common activities alone? & \\
\hline & Did the treatment of your ulcers make your daily activities difficult? & \\
\hline & Did your ulcers make bathing difficult? & \\
\hline \multirow[t]{12}{*}{ Psychological } & Did your ulcers make your embarrassed? & \\
\hline & Did your ulcers make your uneasy in relation to other people? & \\
\hline & Did your ulcers make you angry? & \\
\hline & Did your ulcers make you lack confidence in yourself? & \\
\hline & Did your ulcers make you sad because of delayed healing? & \\
\hline & Were you concerned by the possibility of the ulcers never healing? & \\
\hline & Did your ulcers make you sad or depressed? & \\
\hline & Did your ulcers make you frustrated or disillusioned? & \\
\hline & Were you concerned that the ulcers would worsen? & \\
\hline & Did your ulcers make you easily irritated? & \\
\hline & Did your ulcers make your feel ugly or unattractive? & \\
\hline & Did your ulcers prevent you from using the clothes you like? & \\
\hline \multirow[t]{10}{*}{ Symptoms } & Did your ulcers burn or sting? & \\
\hline & Did your ulcers hurt? & \\
\hline & Did the skin around the ulcer become irritated? & \\
\hline & Did the skin around the ulcer itch? & \\
\hline & Did the skin around the ulcer become sensitive? & \\
\hline & Did your ulcers make sleeping difficult? & \\
\hline & Did your ulcers prevent you from relaxing or resting? & \\
\hline & Did your ulcers make you feel tired? & \\
\hline & Did your ulcers emit fluid or pus? & \\
\hline & Did your ulcers have a disagreeable /bad smell? & \\
\hline
\end{tabular}


latent structure of the original instrument, enabling it to be used in assessing the QoL in chronic venous legal ulcer in Brazil.

More than just an assessment index for the outcomes of clinical studies, the QoL evaluation is important for demonstrating the perception of the disease from the patient's point of view. As the treatment of patients with $\mathrm{VU}$ involves an extended healing time, the VLU-QoL-Br permits the priority dimensions to be identified for intervention while caring for the lesion, aimed at the overall care of the patient.

The questionnaire was achieved high acceptance among patients, despite the time for completion by some patients limiting its use in clinical practice. Other generic constructs such as the WHOQOL (The World Health Organization Quality of Life) and SF-36 (The Short Form Health Survey) are longer and, like the DLQI (Dermatologic Life Quality Index), do not specifically represent the impacts inflicted by VUs. ${ }^{18}$

It was also demonstrated that the use of generic instruments is not always adequate owing to their lack of sensitivity and incapacity to identify change in QoL in relation to the characteristics of the ulcer and its consequences, such as chronicity, recurrence, natural course of the disease, pain, odor, edema, exudates, limitation of mobility, physical appearance, emotional and social aspects the effect of these variables on quality of life. ${ }^{19}$

Gonzalez-Consuegra and Verdu, in a review of 22 studies, verified the negative impact of VUs on the QoL of patients. In these studies, the impact was measured using various types of instruments. ${ }^{20}$ Another systematic review conducted to evaluate the impact of chronic leg ulcers on the QoL of patients suggested that they are significantly exposed to more pain, functional and social restrictions, lower vitality and limitations in relation to emotional aspects when compared to controls. ${ }^{21}$

There are some specific constructs for evaluating the QoL of VU patients with proven reliability and validity. Those studied most are the Hyland ${ }^{22}$ and Charing Cross Venous Leg Ulcer Questionnaire. ${ }^{8}$ The Sheffield Preference-based Venous Leg Ulcer 5 (SPVLU-5D) and Venous Leg Ulcer Quality of Life (VLU-QoL) instruments are the newest and most promising, owing to the structure of the items evaluated, and they require validation in other languages, such as Brazilian Portuguese. ${ }^{20}$

The test-retest reliability of the VLU-QoL-Br displayed a positive bias in the first interview compared to the second. This may have occurred as a result of the second interview in the clinical follow-up during treatment and after medical intervention, leading to possible modification of the cli- nical symptoms during the observation time. This hypothesis is strengthened when noting the greater concordance in the interviews conducted in less than one month.

In a multivariate analysis, higher VLU-QoL-Br scores are associated with large areas affected by ulcers, corroborating the correlation between the physical dimension of the disease and the impact on QoL. The same aspect was identified in other venous ulcer QoL studies and in the development of the original questionnaire. ${ }^{11,23}$

The ethnical and cultural variations of the population groups studied and their specific representation of the health/disease phenomenon are critical to the universalization of versions of QoL questionnaires developed for specific populations. ${ }^{24-28}$ In this case, the VLU-QoL, originally British and based on the Skindex-29 and 19 sub-items established by focus groups started with 48 questions that resulted in the current structure. However, it did not explore aspects connected to the impact of religious syncretism, married life or sexuality of patients, elements that are characteristically present in the reality of Latin populations.

Despite the high internal consistency and test-retest reliability, the relative length of the questionnaire ( 34 items) leads to completion for more than 15 minutes and does not cover spiritual aspects or those related to conjugal intimacy. These arguments may justify the development of a new instrument for assessing QoL in VU.

The special characteristics of those with VU attending university based public services, as targeted in this study, should be reiterated: more serious and chronic cases, and patients with a low social and educational level. These aspects did not prevent the validation of the instrument per se; however, despite its good psychometric performance, they allude to the possibility of investigating its performance in different population groups.

\section{Conclusion}

The translation, adaptation and validation of the VLU-QoL-Br questionnaire were concluded, demonstrating good psychometric performance, and enabling its clinical use in Brazil. It is important to evaluate its performance in other regions and different samples of individuals.

\section{Ethical aspects}

The authors declare that there are no conflicts of interest related to the products or the results of this study. There was not direct or indirect benefit to the authors or volunteers in the study. The project was approved by the institution's research ethics committee $\left(\mathrm{n}^{\circ} .57 / 2012\right.$ on $3 / 5 / 2012)$. 
Financing: Project financed by the FAPESP (2012/01551-08).

\section{Resumo}

Tradução, adaptação cultural para o Brasil e validação do questionário sobre qualidade de vida em úlceras venosas de membros inferiores (VLU-QoL-Br)

Objetivo: traduzir o instrumento Venous legulcer quality of life questionnaire (VLU-QoL), adaptá-lo culturalmente para o português do Brasil e validá-lo com pacientes do Hospital das Clínicas da Faculdade de Medicina de Botucatu (FMB) da Universidade Estadual Paulista (Unesp). Métodos: o questionário foi traduzido por um tradutor profissional e por dois dermatologistas especialistas na área de úlceras venosas (UV), sendo reformulado em reunião com os três tradutores. O constructo (VLU-QoL-Br) foi submetido a pré-entrevista com 10 portadores de UV para a adaptação da linguagem. Posteriormente, foi aplicado em pacientes do HC-Unesp, e como teste-reteste para verificação de sua reprodutibilidade.

Resultados: foram avaliados 82 pacientes, sendo 56 (68\%) do sexo feminino. A idade média foi de 67,3 anos. O questionário foi traduzido, adaptado e aplicado aos pacientes. $O$ constructo apresentou alta consistência interna $($ alfa $=0,94)$ e adequada correlação item-total. Quando avaliados os 32 retestes, observou-se correlação intraclasse para concordância de $0,78(\mathrm{p}<0,01)$, indicando boa reprodutibilidade do constructo. A análise fatorial confirmatória corroborou as dimensões do questionário original: atividades, psicológico e sintomas. Escores do VLU-QoL-Br se associaram, independentemente, à área total das úlceras e a menor escolaridade dos sujeitos ( $\mathrm{p}<0,01)$. Conclusão: a tradução, a adaptação e a validação do questionário VLU-Qol-Br demonstrou boa performance psicométrica, permitindo seu uso clínico no Brasil. É importante avaliar seu desempenho em outras regiões e em diferentes amostras de indivíduos.

Unitermos: úlcera da perna; insuficiência venosa; úlcera varicosa; qualidade de vida; estudos de validação.

\section{References}

1. Abbade LP, Lastoria S. Venous ulcer: epidemiology, physiopathology, diagnosis and treatment. Int J Dermatol. 2005;44:449-56.

2. Miot HA, Mendacolli TJ, Costa SV, Haddad GR, Abbade LP. [Chronic ulcers of the lower limbs: area evaluation by digital photography]. Rev Assoc Med Bras. 2009;55:145-8.
3. Maffei FH, Magaldi C, Pinho SZ, Lastoria S, Pinho W, Yoshida WB, et al. Varicose veins and chronic venous insufficiency in Brazil: prevalence among 1755 inhabitants of a country town. Int J Epidemiol. 1986;15:210-7.

4. Abbade LP, Lastoria JC. Abordagem de pacientes com úlcera da perna de etiologia venosa. An Bras Dermatol. 2006;81:509-22.

5. Abbade LP, Lastoria S, de Almeida Rollo H, Stolf HO. A sociodemographic, clinical study of patients with venous ulcer. Int J Dermatol. 2005;44:98992.

6. Persoon A, Heinen MM, van der Vleuten CJ, de Rooij MJ, van de Kerkhof PC, van Achterberg T. Leg ulcers: a review of their impact on daily life. J Clin Nurs. 2004;13:341-54.

7. Couto RC, Leal FJ, Bezerra RCB, Segundo WSS. Tradução e adaptação cultural do Charing Cross Venous Ulcer Questionnaire - Brasil. J Vasc Bras. 2012;11:102-7.

8. Smith JJ, Guest MG, Greenhalgh RM, Davies AH. Measuring the quality of life in patients with venous ulcers. J Vasc Surg. 2000;31:642-9.

9. Launois R, Reboul-Marty J, Henry B. Construction and validation of a quality of life questionnaire in chronic lower limb venous insufficiency (CIVIQ). Qual Life Res. 1996;5:539-54.

10. Klyscz T, Junger M, Schanz S, Janz M, Rassner G, Kohnen R. [Quality of life in chronic venous insufficiency (CVI). Results of a study with the newly developed Tubingen Questionnaire for measuring quality of life of patients with chronic venous insufficiency]. Hautarzt. 1998;49:372-81.

11. Hareendran A, Doll H, Wild DJ, Moffatt CJ, Musgrove E, Wheatley C, et al. The venous leg ulcer quality of life (VLU-QoL) questionnaire: development and psychometric validation. Wound Repair Regen. 2007;15:465-73.

12. Miot HA. Tamanho da amostra em estudos clínicos e experimentais. J Vasc Bras. 2011;10:275-8.

13. Viana HB, Madruga VA. Diretrizes para adaptação cultural de escalas psicométricas; 2008. [citado 10 maio 2013]. Disponível em: http://www. efdeportes.com.

14. Norman GR, Streiner DL. Biostatistics. The bare essentials. 3rd ed. Shelton, Connecticut: People's Medical Publishing House; 2008.

15. Vargha P. A critical discussion of intraclass correlation coefficients. Stat Med. 1997;16:821-3.

16. Bland JM, Altman DG. Statistical methods for assessing agreement between two methods of clinical measurement. Lancet. 1986;1:307-10.

17. IBM SPSS 20.0 for Windows. 20th ed. Chicago: SPSS Incorporation; 2011:Statistical Package for Social Science (SPSS).

18. Silvares MR, Fortes MR, Miot HA. Quality of life in chronic urticaria: a survey at a public university outpatient clinic, Botucatu (Brazil). Rev Assoc Med Bras. 2011;57:577-82.

19. van Korlaar I, Vossen C, Rosendaal F, Cameron L, Bovill E, Kaptein A. Quality of life in venous disease. Thromb Haemost. 2003;90:27-35.

20. Gonzalez-Consuegra RV, Verdu J. Quality of life in people with venous leg ulcers: an integrative review. J Adv Nurs. 2011;67:926-44.

21. Herber OR, Schnepp W, Rieger MA. A systematic review on the impact of leg ulceration on patients' quality of life. Health Qual Life Outcomes. 2007;5:44.

22. Hyland ME, Ley A, Thomson B. Quality of life of leg ulcer patients: questionnaire and preliminary findings. J Wound Care. 1994;3:294-8.

23. Pieper B, Szczepaniak K, Templin T. Psychosocial adjustment, coping, and quality of life in persons with venous ulcers and a history of intravenous drug use. J Wound Ostomy Continence Nurs. 2000;27:227-37.

24. Laurenti R. A mensuração da qualidade de vida. Rev Assoc Med Bras. 2003;49:361-2

25. Staniszewska S, Ahmed L, Jenkinson C. The conceptual validity and appropriateness of using health-related quality of life measures with minority ethnic groups. Ethn Health 1999;4:51-63.

26. Schalock RL, Verdugo MA, Jenaro C, Wang M, Wehmeyer M, Jiancheng X, et al. Cross-cultural study of quality of life indicators. Am J Ment Retard. 2005;110:298-311.

27. Penha MA, Santos PM, Miot HA. Dimensioning the fear of dermatologic diseases. An Bras Dermatol. 2012;87:796-9.

28. Gill TM, Feinstein AR. A critical appraisal of the quality of quality-of-life measurements. JAMA. 1994;272:619-26. 